\title{
SISTEM INFORMASI GEOGRAFIS DIARE PADA BALITA DI WILAYAH KERJA PUSKESMAS BANJARBARU
}

\author{
Noraida, Abdul Khair, Munawar Raharja \\ Poltekkes Kemenkes Banjarmasin Jurusan Kesehatan Lingkungan Banjarbaru \\ Jl. H.Mistar Cokrokusumo No. 1A Kota Banjarbaru \\ e-mail : noraida1972@gmail.com
}

\begin{abstract}
Geographic Information System of Diarrhea in Children in the Area of Puskemas Kota Banjarbaru. Incidence of diarrhea was always found every year in Banjarbaru. Incidence rate of diarrhea in Banjarbaru in 2009 to 2012 are respectively 20.98, 19.86, and 16.39. The presentation of data on the incidence of diarrhea mainly done using tables and graphs. The aim of the study was to describe the incidence of diarrhea in children aged less than 5 years in the area of Puskemas Kota Banjarbaru using geographic information system. This research is a descriptive study. Four of the eight health centers in Banjarbaru was chosen as samples. All children aged less than 5 years old who suffered from diarrhea in the four regions had been recorded. Furthermore, measurements of the coordinates of the house where there is a child aged less than 5 years of the living was done. Based on data from the coordinates, thematic maps of the incidence of diarrhea was made. The results showed that during the months of January to June 2013, the incidence of diarrhea is solid in the areas of Puskesmas Banjarbaru and Puskesmas Sungai Besar, is width in the Puskesmas Sungai Ulin, and is solid and long in the area of Puskesmas Cempaka. The results showed that during the months of January to June 2013, the incidence of diarrhea is solid in the areas of Puskesmas Banjarbaru and Puskesmas Sungai Besar, is width in the Puskesmas Sungai Ulin, and is solid and long in the area of Puskesmas Cempaka. It is recommended that a follow-up is done in order to prevent or reduce the incidence of diarrhea through concrete and effective interventions.
\end{abstract}

Keywords : Diarrhea; GIS; Banjarbaru

\begin{abstract}
Abstrak : Sistem Informasi Geografis Diare pada Balita di Wilayah Kerja Puskesmas Kota Banjarbaru. Kasus diare merupakan kejadian yang terus saja ditemukan setiap tahun di Kota Banjarbaru (delapan Kecamatan). Data dari Dinas Kesehatan Kota Banjarbaru menunjukkan Incidence Rete (IR) kejadian diare pada tahun 2009 sebesar 20,98, tahun 2010 sebesar 19,86, dan hingga bulan November pada tahun 2012 sebesar 16,39. Selama ini kegiatan pengelolaan kejadian diare telah dilakukan oleh Dinas Kesehatan Kota Banjarbaru terutama dengan pengumpulan data bulanan dan direkapitulasi secara rutin. Pengolahan dan analisis data secara diskriptif terutama dilakukan menggunakan tabel dan grafik. Penelitian bertujuan memahami kejadian diare pada balita di Wilayah Kerja Puskesmas Kota Banjarbaru tahun 2013. Jenis penelitian adalah deskriptif. Dipilih 4 (empat) wilayah kerja Puskesmas sebagai sampel dari 8 (delapan) puskesmas yang ada di Kota Banjarbaru. Semua balita yang menderita diare yang tercatat dengan baik di masing-masing puskesmas terpilih diambil data titik koordinat tempat tinggalnya. Selanjutnya dilakukan deskripsi spasial berdasarkan peta tematik kejadian diare yang diperoleh. Hasil penelitian menunjukkan bahwa kejadian diare selama bulan Januari sampai Juni 2013 di wilayah kerja Puskesmas Banjarbaru dan Puskesmas Sungai Besar membentuk sebaran yang rapat, di wilayah kerja Puskesmas Sungai Ulin membentuk pola sebaran meluas, dan di wilayah kerja Puskesmas Cempaka membentuk beberapa sebaran rapat dan memanjang sepanjang alur jalan. Disarankan agar ditindaklanjuti dalam rangka mencegah ataupun menurunkan angka kejadian diare dengan upaya-upaya konkrit berupa intervensi metode pencegahan diare yang efektif.
\end{abstract}

Kata Kunci : : SIG; Diare; Banjarbaru

\section{PENDAHULUAN}

Surveilan adalah suatu proses pengamatan terus menerus dan sistematik terhadap terjadinya penyebaran penyakit serta kondisi yang memperbesar risiko penularan dengan melakukan pengumpulan data, analisis, interpretasi dan penyebaran interpretasi serta tindak lanjut perbaikan dan perubahan. Surveilance for action memerlukan aktivitas penting surveilan yang harus 
selalu sustainable meliputi proses pengumpulan data epidemiologi secara sistematis sebagai aktivitas rutin, pengolahan dan analisis serta interprestasi data agar menghasilkan informasi epidemiologi, aktivitas yang terakhir yaitu penggunaan informasi untuk menentukan tindakan perbaikan yang perlu dilakukan atau peningkatan program dalam menyelesaikan masalah (1).

Di Kota Banjarbaru (dengan delapan kecamatan) kejadian diare merupakan penyakit yang terus saja ditemukan setiap tahun. Incidence Rate (IR) kejadian diare pada tahun 2009 sebesar 20,98, tahun 2010 sebesar 19,86, tahun 2011 sebesar 29,33, dan hingga bulan November pada tahun 2012 sebesar 16,39 (1). Diare dapat disebabkan oleh banyak faktor. Akan tetapi, penyebab terbanyak diare akut pada anak khususnya balita adalah rotavirus. Rotavirus ditularkan lewat faecal oral sedangkan penularan oleh bakteri dipengaruhi kondisi lingkungannya terutama sumber air bersih yang digunakan (water borne), sehingga seorang balita yang terkena diare merupakan sumber penyebaran ke populasi sekitar (2).

Selama ini kegiatan pengelolaan kejadian diare telah dilakukan oleh Dinas Kesehatan Kota Banjarbaru terutama dengan pengumpulan data bulanan dan direkapitulasi secara rutin. Pengolahan dan penyajian data secara diskriptif terutama dilakukan menggunakan tabel dan grafik. Penggunaan aplikasi Sistem Informasi Geografis (SIG) untuk pengkajian kejadian penyakit belum begitu populer.

Sistem informasi geografis (SIG) dinyatakan sebagai kumpulan yang terorganisir dari perangkat keras komputer, perangkat lunak, data geografi, dan personil yang dirancang secara efisien untuk memperoleh, menyimpan, meng-update, memanipulasi, menganalisis, dan menampilkan semua bentuk informasi yang bereferensi geografi (3). Salah satu perkembangan Sistem Informasi Geografis yang menarik adalah epidemiologi spasial (spatial epidemiology). Spasial epidemiologi adalah ilmu untuk mendeskripsikan dan menganalisis keragaman geografis pada penyakit dengan memperhatikan dimensi geografis, lingkungan, prilaku, sosial ekonomi, gene- tika dan faktor risiko penularan. Epidemiologi spasial ini menghasilkan pemetaan penyakit (diseases mapping), studi korelasi geografis (geographical correlation studies), pengelompokan penyakit (diseases kluster), dan survailans (4).

Pengalaman menunjukkan bahwa meskipun upaya pengembangan sistem informasi geografis di sektor kesehatan sudah dirintis sejak lama, khususnya untuk pemberatasan dan pencegahan penyakit menular, namun hingga saat ini dampak dan manfaatnya belum terasa (5). Oleh karena itu dilakukan penelitian untuk mengkaji kejadian diare pada balita di Wilayah Kerja Puskesmas Kota Banjarbaru dan faktor risikonya sebagai bagian upaya pengembangan sistem informasi geografis di Kota Banjarbaru. Variabel-variabel faktor risiko yang akan diteliti adalah variabel-variabel yang dapat mempengaruhi peningkatan kasus diare yaitu jumlah dan distribusi penduduk, curah hujan, dan kondisi lingkungan yang mempengaruhi distribusi khususnya yang dikarenakan bakteri seperti sumber air bersih, jamban, dan tempat pembuangan sampah. Variabel dipilih untuk diteliti karena variabel-variabel tersebut meru-pakan komponen yang dapat diukur dan dapat diintervensi.

\section{BAHAN DAN CARA PENELITIAN}

Berdasarkan analisis datanya, penelitian ini termasuk penelitian deskriptif yaitu menggambarkan kejadian diare kejadian diare pada balita di Wilayah Kerja Puskesmas Kota Banjarbaru tahun 2013.

Populasi dalam penelitian ini adalah seluruh kejadian diare pada balita di Wilayah Kerja Puskesmas Kota Banjarbaru Tahun 2013. Sampel adalah seluruh kejadian diare pada balita di Wilayah Kerja Puskesmas Sungai Besar, Sungai Ulin, Cempaka, dan Banjarbaru dalam periode waktu 6 (enam) bulan yaitu Januari s.d. Juni 2013, dengan kriteria inklusi adalah balita yang bertempat tinggal di Wilayah Kerja Puskesmas Sungai Besar, Sungai Ulin, Cempaka, dan Banjarbaru dan kriteria eksklusi adalah balita yang meninggal dunia.

Data yang dikumpulkan meliputi: data sekunder kasus diare pada balita di Wilayah 
Kerja Puskesmas Sungai Besar, Sungai Ulin, Cempaka, dan Banjarbaru, data curah hujan, diperoleh secara sekunder dari Badan Meteorologi Klimatologi dan Geo-fisika (BMKG) Stasiun Klimatologi Banjarbaru dan pengukuran koordinat lokasi kasus (rumah penderita, sarana air bersih, jamban dan pengelolaan sampah) dengan menggunakan GPS Super Spring SF 510.

Analisis data menggunakan Analisis pemodelan spasial faktor lingkungan dan sebaran kasus diare dengan proses tumpang susun/overlay, menentukan zona tingkat kerawanan penyakit diare. Analisa data spasial dengan bantuan software epi info (epimap) yang memiliki kemampuan untuk memvisualisasikan, mengeksplorasi, memi-lah-milah data dan menganalisis data secara spasial. Software ArcGis digunakan dalam digitasi batas-batas wilayah dari 4 (empat) wilayah kerja Puskesmas yang menjadi lokasi penelitian. Data titik koordinat kejadian diare pada balita di Wilayah Kerja Puskesmas Kota Banjarbaru yang diperoleh menggunakan GPS dan informasi spasial seperti jumlah dan distribusi balita, besar curah hujan, dan jenis sarana kesehatan lingkungan selanjutnya ditransfer ke "Map Source".

\section{HASIL PENELITIAN DAN PEMBAHASAN}

Jumlah kasus di Wilayah Kerja Puskesmas Banjarbaru, Sungai Besar, Sungai Ulin, dan Cempaka selama 6 (enam) bulan yaitu Januari s.d. Juni 2013 sebanyak 233 kasus dengan jumlah balita sebanyak 6413 . Distribusi kasus diare pada 4 (empat) Wilayah Kerja Puskesmas di Kota Banjarbaru bulan Januari s.d. Juni 2013 ditunjukkan pada Gambar 1.

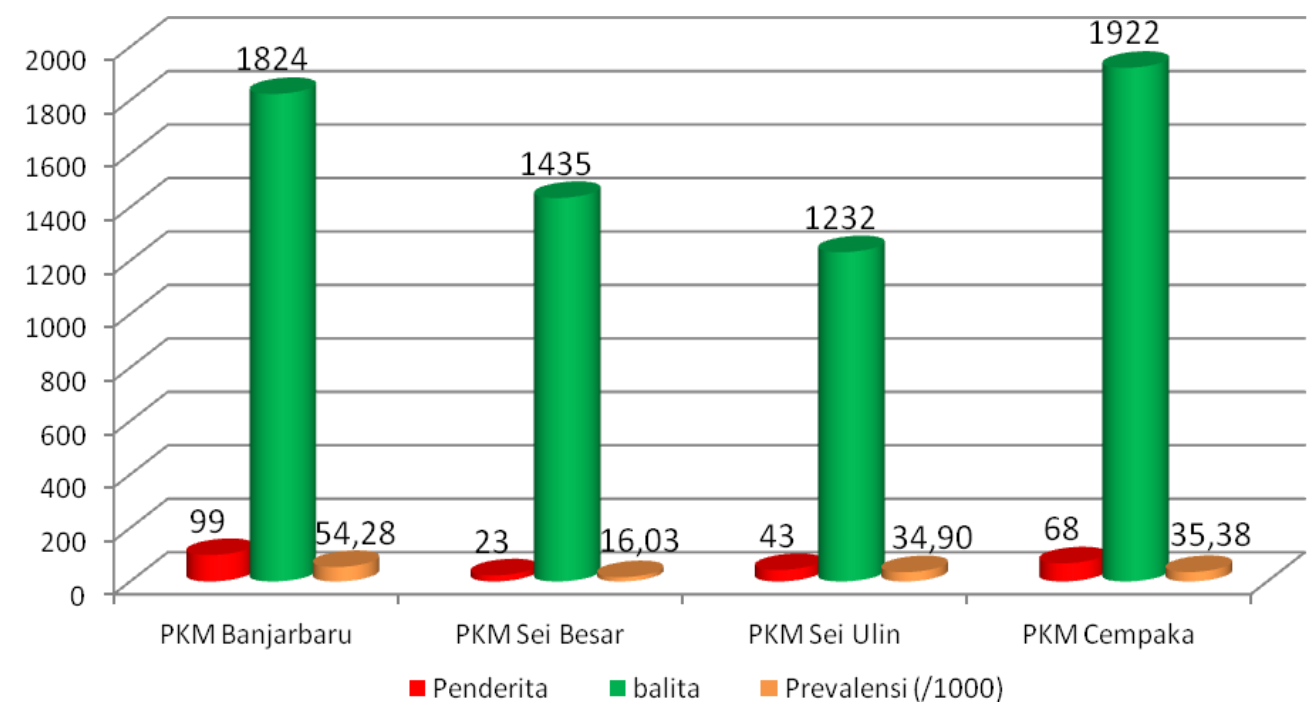

Gambar 1. Distribusi Kasus Diare pada Empat Wilayah Kerja Puskesmas di Kota Banjarbaru Januari s.d. Juni 2013

Berdasarkan Gambar 1 dapat dikatakan bahwa jumlah kasus diare pada balita yang terjadi pada bulan Januari s.d Juni 2013 berkisar antara 23 s.d 99 kasus. Kasus diare paling sedikit (23 kasus) terjadi di Wilayah Kerja Puskesmas Sungai Besar dan paling banyak (99 kasus) terjadi di Wilayah Kerja Puskesmas Banjarbaru. Jumlah balita pada bulan Januari s.d Juni 2013 berkisar antara 1232 s.d 1922 balita. Jumlah balita paling sedikit (1232 balita) terdapat di
Wilayah Kerja Puskesmas Sungai Ulin dan paling banyak (1922 balita) terdapat di Wilayah Kerja Puskesmas Cempaka. Prevalensi (/1000) kasus diare pada bulan Januari s.d Juni 2013 berkisar antara 16,03 s.d 54,28. Prevalensi (/1000) terendah $(16,03)$ terjadi di Wilayah Kerja Puskesmas Sungai Besar dan tertinggi $(54,28)$ terjadi di Wilayah Kerja Puskesmas Banjarbaru.

Berdasarkan data Stasiun Klimatologi BMKG Banjarbaru diketahui bahwa ke- 
empat Wilayah Kerja Puskesmas di Kota Banjarbaru yaitu Puskesmas Banjarbaru, Sungai Besar, Sungai Ulin, dan Cempaka masih dalam satu lingkup pengamatan, sehingga dapat dikatakan bahwa rata-rata curah hujan di empat Wilayah Kerja Puskesmas tersebut adalah serupa. Sebagai gambaran bahwa curah hujan antara tahun 2010 s.d 2012 berkisar antara 21,3 s.d 856,8 milimeter dengan rata-rata 246,5 milimeter.
Jenis sarana air bersih di Wilayah Kerja Puskesmas Banjarbaru, Sungai Besar, dan Sungai Ulin terdiri dari PDAM dan sumur. Sedangkan jenis sarana air bersih di Wilayah Kerja Puskesmas Cempaka hanya sumur. Jumlah dan jenis sarana air bersih di Wilayah Kerja Puskesmas Banjarbaru, Sungai Besar, Sungai Ulin dan Cempaka di ditunjukkan pada Gambar 2.

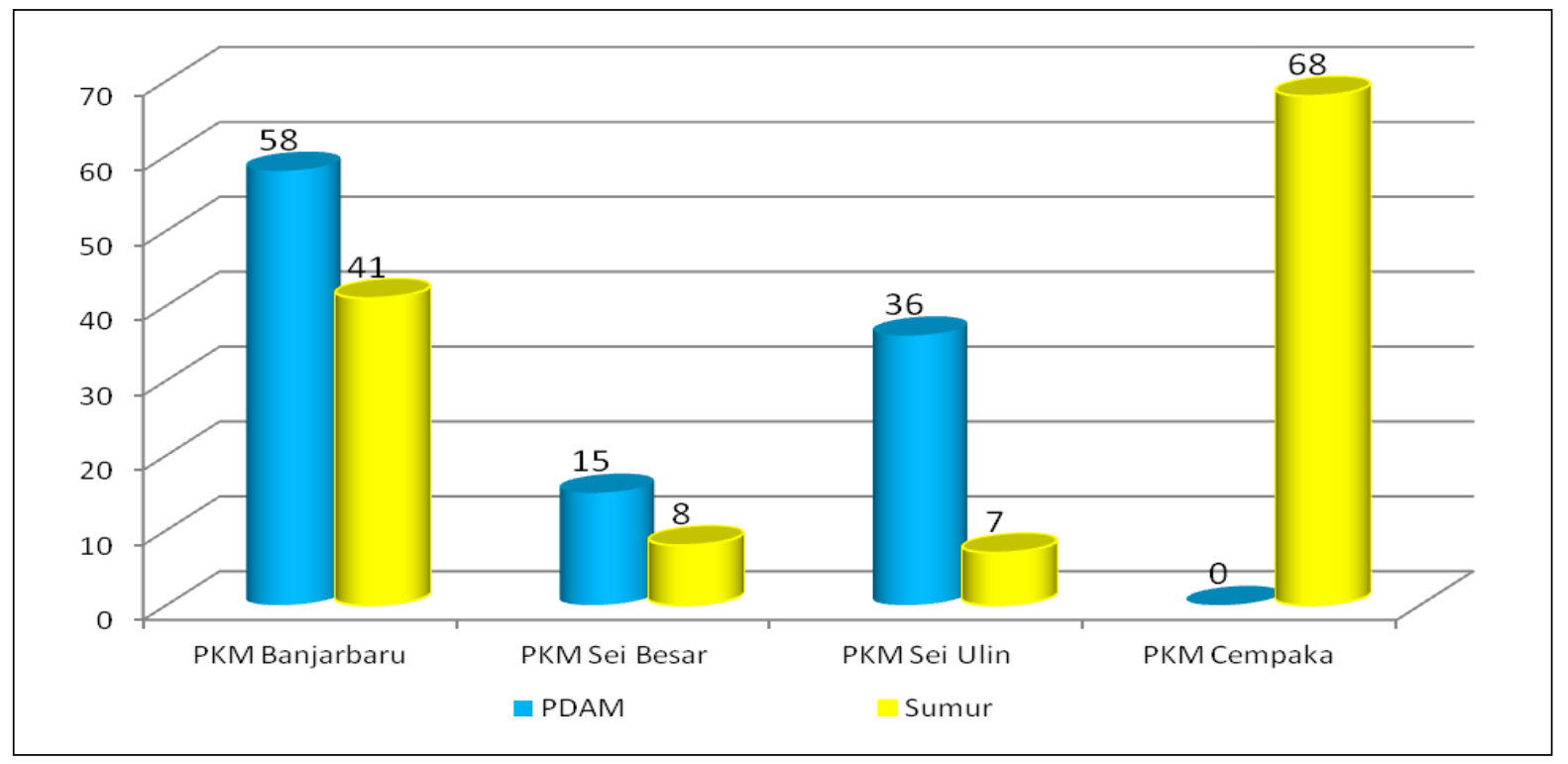

Gambar 2. Distribusi Sarana Air Bersih pada Empat Wilayah Kerja Puskesmas di Kota Banjarbaru Januari s.d. Juni 2013

Kasus diare pada balita yang terjadi pada bulan Januari s.d Juni 2013 berdasarkan jenis sarana air bersih di Wilayah Kerja Puskesmas Banjarbaru, Sungai Besar, dan Sungai Ulin sebagian besar sarana air bersihnya adalah PDAM. Sedangkan kasus diare pada balita yang terjadi pada bulan Januari s.d Juni 2013 berdasarkan jenis sarana air bersih di Wilayah Kerja Puskesmas Cempaka seluruhnya adalah sumur, secara rinci dapat dilihat pada Gambar 3.

Semua rumah keluarga balita yang merupakan kasus diare yang terjadi pada bulan Januari s.d Juni 2013 di Wilayah Kerja Puskesmas Banjarbaru, Sungai Besar, Sungai Ulin, dan Cempaka memiliki jamban sendiri yang berada di dalam rumah.

Semua rumah keluarga balita yang merupakan kasus diare yang terjadi pada bulan Januari s.d Juni 2013 di Wilayah Kerja Puskesmas Banjarbaru, Sungai Besar, Sungai Ulin, dan Cempaka memiliki tempat pembuangan sampah sementara yang berada di depan rumah. 


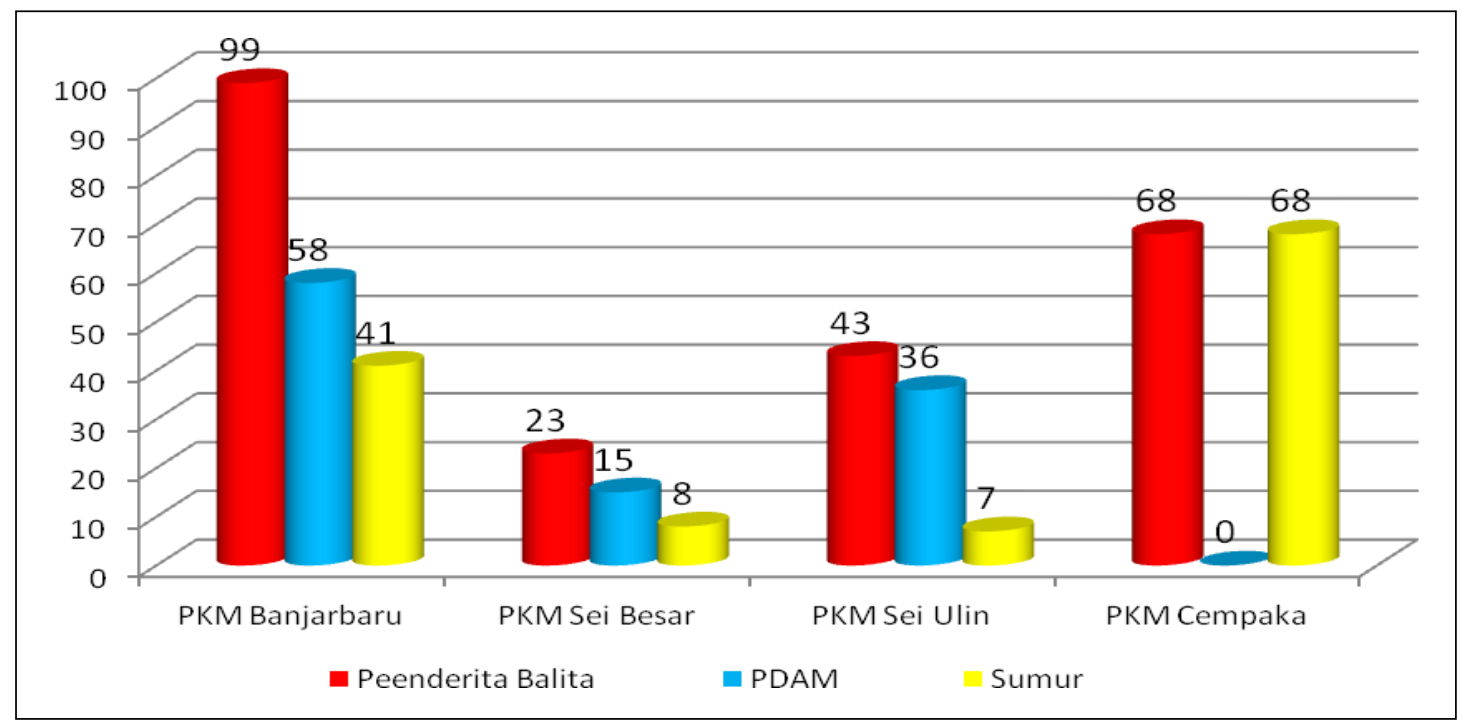

Gambar 3. Kasus Diare Berdasarkan Sarana Air Bersih pada Empat Wilayah Kerja Puskesmas di Kota Banjarbaru Januari s.d. Juni 2013

Berdasarkan data titik koordinat kasus diare dan titik koordinat sarana air bersih (PDAM dan sumur) dilakukan entry data dan proses pengolahan peta tematik.
Peta seperti tampak pada Gambar 4. merupakan peta kejadian diare di 4 (empat) wilayah kerja puskesmas di Kota Banjarbaru bulan Januari sampai Juni 2013.

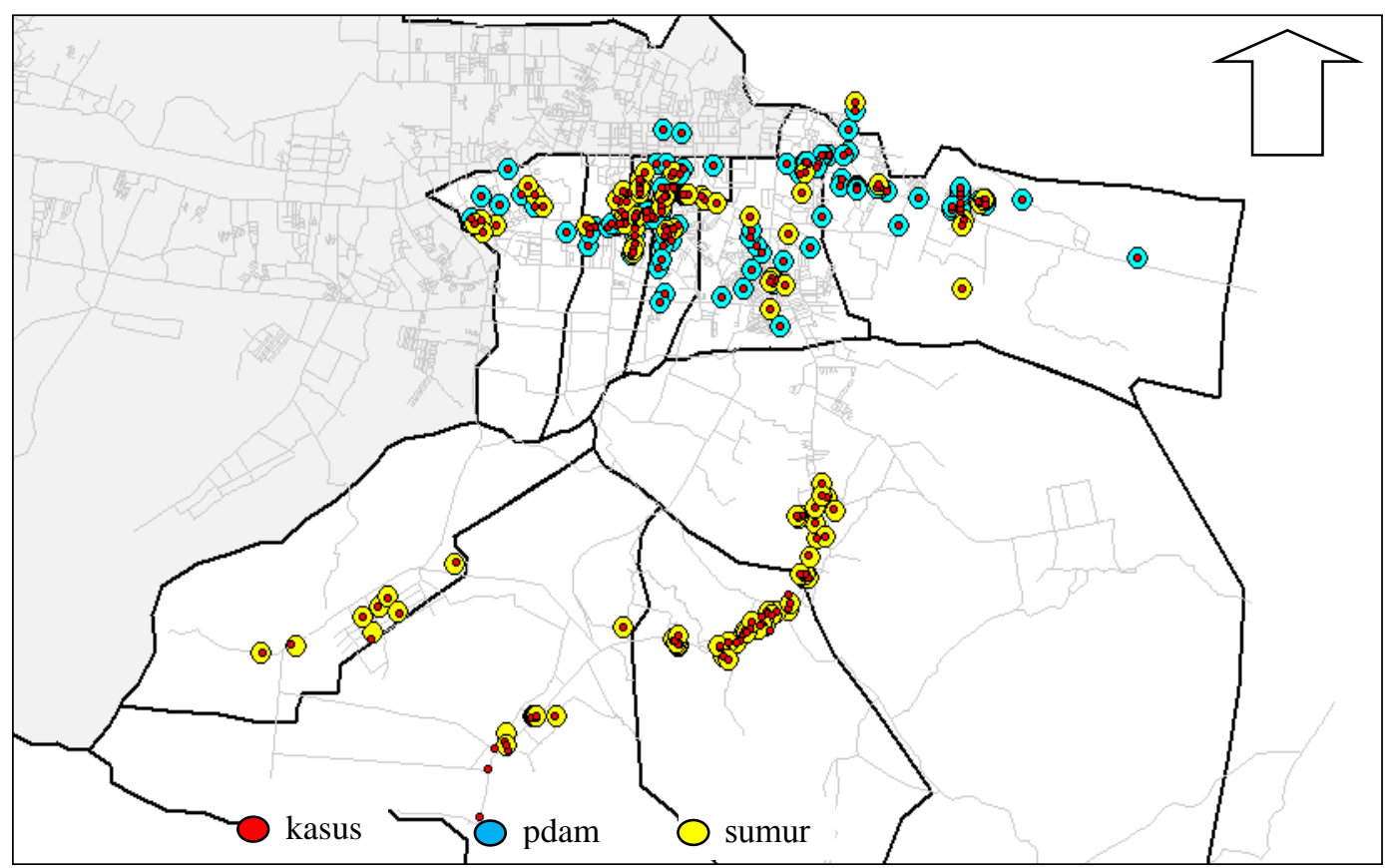

Gambar 4. Peta Kejadian Diare dan Sarana Air Bersih pada Empat Wilayah Kerja Puskesmas di Kota Banjarbaru Januari s.d. Juni 2013

Sebagai salah satu wilayah termuda di Provinsi Kalimantan Selatan, tentu Kota Banjarbaru menjadi terus berkembang. Dari aspek kondisi alam yang sangat menunjang membuat perkembangan Kota Banjarbaru semakin pesat. Keanekaragaman budaya 
juga dapat dengan mudah dilihat di setiap sisi kota. Pemindahan pusat pemerintahan Provinsi Kalimantan Selatan yang sudah sebagian terealisasi merupakan wujud diminatinya Kota Banjarbaru oleh semua pihak sebagai sentral Provinsi Kalimantan Selatan.

Sistem Informasi Geografis (SIG) sebenarnya sudah sangat jamak dimanfaatkan untuk berbagai bidang, diantaranya bidang kehutanan, perkebunan, perikanan, tata kota, dan lain-lain. Di bidang kesehatan sebenarnya sudah di inspirasi dari wabah kolera yang terjadi di London oleh John Snow. Hingga saat ini kegiatan tersebut terus dikembangkan. Sistem informasi geografis dikembangkan terus menerus oleh Centers for Disease Control and Prevention (CDC) di Atlanta, Georgia, Amerika Serikat, berupa perangkat lunak Epi-Info. Salah satu fasilitas yang ada di dalamnya adalah Epi-Map. Perangkat lunak ini dirancang untuk keperluan bidang epidemiologi.

Sistem Informasi Geografis kejadian diare yang dikembangkan dalam penelitian ini menggunakan bantuan paduan 2 (dua) software, yaitu ArcGIS 10 dan EpiMap. ArcGIS dimanfaatkan sebagai alat dalam pembuatan batas-batas, yaitu batas kota, batas kecamatan, dan batas kelurahan. Kegiatan ini nampaknya agak sulit apabila dilakukan dengan EpiMap. Sedangkan EpiMap sendiri dimanfaatkan dalam pengolahan peta tematik karena kemudahan dan kepraktisannya dan memang dirancang untuk bidang kesehatan. Bahkan software ini terus dikembangkan dengan sistem berbasis internet yaitu dengan dirilisnya EpiInfo 7.

Hasil pemetaan kejadian diare di empat wilayah kerja puskesmas di Kota Banjarbaru bulan Januari sampai Juni 2013 kejadian diare, diketahui bahwa kejadian diare pada bulan Januari sampai Juni 2013 dengan visualisasi "warna merah" terlihat banyak pada wilayah kerja Puskesmas Banjarbaru. Sarana air bersih berupa sumur dengan visualisasi "warna kuning" terdapat pada keempat wilayah kerja puskesmas, namun sarana berupa PDAM dengan visualisasi "warna biru" tidak nampak pada wilayah kerja Puskesmas Cempaka. Nampak pula pada bahwa kejadian diare pada masing-masing wilayah kerja mempunyai sebaran-sebaran yang khas. Di wilayah kerja Puskesmas Banjarbaru dan Puskesmas Sungai Besar, nampak sebaran kejadian diare yang memusat pada satu titik. Namun pada wilayah kerja Puskesmas Sungai Ulin nampak terjadinya kejadian diare mempunyai sebaran yang agak meluas. Sedangkan pada wilayah kerja Puskesmas Cempaka nampak kejadian diare membentuk sebaran memusat dengan suatu alur garis memanjang. Hal tersebut sangat berkaitan dengan pola tempat tinggal masyarakat yaitu di sepanjang alur jalan raya.

Peta kejadian diare di wilayah kerja Puskesmas Banjarbaru bulan Januari sampai Juni 2013, sebaran-sebaran kejadian semakin nampak jelas. Sarana lingkungan yang agak mudah dikaitkan adalah berupa sarana air bersih. Nampak bahwa perbandingan pemakaian sarana air bersih berupa PDAM relatif sebanding dengan pemakaian sarana air bersih berupa sumur gali. Hal ini dapat menjelaskan bahwa variabel sarana air bersih yang dipakai oleh keluarga dimana balita yang menderita diare tersebut tidaklah berkaitan. Oleh karena itu, berdasarkan peta memunculkan dugaan bahwa faktor lain seperti perilaku dan pengaruh gaya hidup masyarakat lingkungannya dapat menjadi variabel menarik untuk penelitian lebih lanjut.

Kejadian diare di wilayah kerja Puskesmas Sungai Besar seperti Gambar 4 nampak serupa dengan kejadian seperti kejadian diare di wilayah kerja Puskesmas Banjarbaru. Meskipun demikian sebaran kejadian diare nampak tidak terlalu berdekatan dibandingkan wilayah kerja Puskesmas Banjarbaru. Hal ini memunculkan dugaan hanya karena pengaruh faktor perilaku.

Pada peta kejadian diare bulan Januari sampai Juni 2013 di wilayah kerja Puskesmas Sungai Ulin. Meskipun diketahui bahwa prevalensi kejadian diare di wilayah kerja Puskesmas Sungai Ulin lebih besar dibandingkan di wilayah kerja Puskesmas Sungai Besar, namun bila dibandingkan luasan wilayah maka dapat dikatakan bahwa kejadian diarenya lebih rendah. Hal tersebut 
sangat nampak dimana kejadian diare menampakkan sebaran yang agak meluas.

Kejadian diare di wilayah kerja Puskesmas Cempaka bulan Januari sampai Juni 2013 nampak membentuk sebaran memanjang dan berhimpitan. Hal ini menimbulkan dugaan untuk penelitian lebih lanjut berupa perilaku, pengaruh gaya hidup lingkungan, dan tentu saja kondisi air pada sarana sumur yang digunakan oleh masyarakat untuk keperluan hidupnya sehari-hari.

\section{KESIMPULAN DAN SARAN}

Kejadian diare selama bulan Januari sampai Juni 2013 di wilayah kerja Puskesmas Banjarbaru dan Puskesmas Sungai Besar membentuk sebaran yang rapat, di wilayah kerja Puskesmas Sungai Ulin membentuk pola sebaran meluas, dan di wilayah kerja Puskesmas Cempaka membentuk beberapa sebaran rapat dan memanjang sepanjang alur jalan. Kejadian diare di wilayah kerja Puskesmas Banjarbaru, Puskesmas Sungai Besar, Puskesmas Sungai Ulin, dan Puskesmas Cempaka tidak dapat dibedakan berdasarkan curah hujan, karena berdasarkan data yang diperoleh dari Stasiun Klimatologi BMKG Banjarbaru keempat wilayah tersebut berada dalam satu kategori. Jenis sarana kesehatan lingkungan yang dapat dikaitkan dalam penelitian adalah sarana air bersih berupa PDAM dan sumur gali dan dapat dikatakan bahwa perbedaan jenis sarana air bersih yang digunakan tidak menunjukkan gambaran perbedaan dalam kejadian diare.

Penggunaan citra resolusi tinggi yang meliputi wilayah Kota Banjarbaru keseluruhan akan lebih menggambarkan kondisi Kota Banjarbaru secara lengkap, baik di daerah yang berisiko Diare maupun daerah yang tidak berisiko.

Gambaran kejadian diare di keempat wilayah kerja puskesmas menggunakan Sistem Informasi Geografis (SIG) dalam penelitian ini perlu ditindaklanjuti dalam rangka mencegah ataupun menurunkan angka kejadiannya dengan upaya-upaya konkrit berupa intervensi metode pencegahan yang efektif.

\section{DAFTAR PUSTAKA}

1. Dinkes Kota Banjarbaru (2012), Rekap Bulanan Data Diare per Puskesmas Tahun 2012, Pengelola Program P2 Diare, Dinas Kesehatan Kota Banjar-baru.

2. Ureani D.W. (2010), Analisis Spasiotemporal Kasus Diare Pada Balita di Kecamatan Tembalang Periode Oktober 2009-Pebruari 2010, Universitas Diponegoro, Semarang.

3. Iswari Lizda (2008), Pemanfaatan Sistem Inferensi Fuzzy Dalam Pengolahan Peta Tematik (Studi Kasus: Sistem Informasi Geografis Daerah Rawan Penyakit Demam Berdarah), Universitas Islam Indonesia, Yogyakarta.

4. Nangi M.G. (2011), Peranan Sistem Informasi Geografis (SIG) Dalam Kesehatan Masyarakat.

5. Rarantean R, 2011. Peranan Sistem Informasi Geografis Kesehatan dalam Bencana. Geoina.blogspot.com/2011/02 diakses 20 September 2013.

6. Prahasta E, 2005, Sistem Informasi Geografis; Konsep-konsep Dasar, edisi Revisi, CV. Informatika, Bandung.

7. Aronoff S., 1989, Geographic Information System: A Management Perspective, WDL Publication : Otawa, Canada. 